
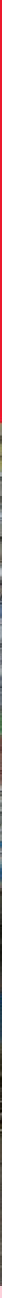

\title{
Making the most of brownfield sites in the Baltic Sea Region
}

Baltic Urban Lab has identified new ways to improve planning processes through public-private-people partnerships - the 4P approach

Brownfield regeneration involves the redevelopment of underutilised areas of a city. This contributes to limiting urban sprawl and promotes investment to restore land that has been contaminated by industrial activity. As such, it is an important path towards more integrated, resilient and sustainable urban development. The European Environment Agency (EEA) estimates that there are three million urban brownfield sites with potential for future regeneration in Europe. In the Baltic Urban Lab project, partners around the Central Baltic Region have identified planning challenges in brownfield regeneration and developed solutions to tackle them through early and broad stakeholder involvement.

OPPORTUNITIES AND CHALLENGES OF BROWNFIELD SITES

This policy brief targets local land use planners, as well as regional and national actors that support local development processes through direct cooperation or policy support. Brownfield regeneration provides a wide range of benefits for sustainable urban development. Ecologically, it limits land consumption 
and preserves natural environments, and can offer a mechanism for cleaning contaminated soil. Economically, buildings can be re-used, and the economic benefits of rejuvenation may spill over into neighbouring communities. Socially, brownfield development can also support more integrated land use, which can, for example, support improvements in urban mobility and recreation areas.

Baltic Urban Lab has shown, however, that there are many common challenges that must be tackled to make brownfield regeneration succeed. For instance, fragmented land ownership and large numbers of stakeholder groups tend to contribute to a lack of a common development vision. The technical, geological, environmental and legal difficulties concerning remediating contaminated land can pose significant challenges, especially financial issues regarding unclear roles and expectations around soil remediation. Cultural heritage protection can also place a variety of limitations on how regeneration can be carried out efficiently.

\section{THE 4P APPROACH - COMBATING CHALLENGES WITH BROAD STAKEHOLDER ENGAGEMENT}

Close cooperation and partnerships between different stakeholders early in a redevelopment process provide an important mechanism for tackling the challenges mentioned above. The Baltic Urban Lab project has involved the cities of Norrköping, Tallinn, Turku and Riga testing new methods of planning for brownfield sites in their cities. They have adopted a publicprivate-people partnership approach, also known as the 4P approach, which is based on the critique that many large-scale urban development projects have involved the public authorities and private developers in a closed process. This produces a low level of transparency for the general public, limiting their ability to contribute to development plans. It can also lead to a higher likelihood of short-term financial goals being prioritised over public benefits and those aspects of liveable communities that support success in the longer term.

The 4P approach emphasises the need to be transparent in the planning process, and to offer possibilities for citizens - "people" - to participate in planning processes. This especially includes early-phase participation, before detailed plans have been finalised, so that stakeholder trust and commitment are established early on, and so that stakeholder contributions have a better chance of being integrated into the development design. It also means that planning is carried out in broad cooperation between various public departments and private sector stakeholders such as land-owners, developers, local enterprises, local citizens and representatives of local interest organisations.

The urban planning pyramid (Figure 1) shows the importance of open dialogue and participation from the beginning of the planning process to create commitment and common understanding between in- volved actors. This helps in the formulation of a common vision and of the goals of a brownfield regeneration project, and it sets a solid base for cooperation in the later stages of the project. This is especially important in brownfield regeneration projects, which often involve higher risks than greenfield development and an additional need for the financing of soil remediation.

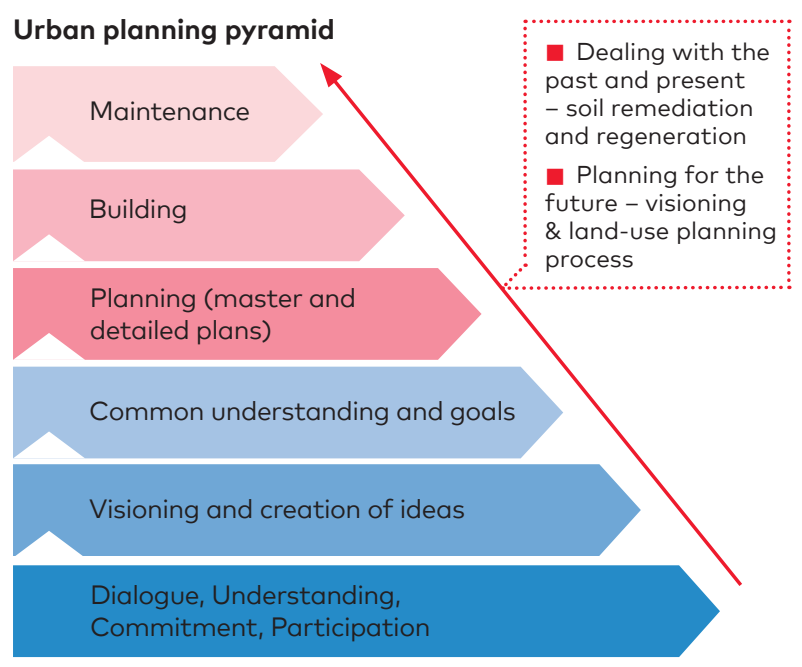

Figure 1: The urban planning pyramid, as included in the guide, Towards integrated and partnershipbased planning of brownfield areas.

\section{GUIDE FOR BROWNFIELD PLANNING AT LOCAL LEVEL}

The guide Towards integrated and partnership-based planning of brownfield sites suggests 10 crucial topics to consider when implementing a 4P approach (see Figure 2). This helps to ensure broad stakeholder cooperation and a common vision during the early stages of a brownfield planning process and, in the bigger picture, it promotes a more integrated and systematic approach to planning brownfield developments. The guide provides additional details about each topic and is based on the partner cities' experience and testing within the Baltic Urban Lab project.

The topics that are marked blue in Figure 2 concern internal organisation and preparation activities that help to start up the planning process in a strategic way. This includes the importance of an initial risk assessment and creating a clear leadership structure and good cooperation between relevant departments in the public sector. The importance of agreeing on the legal status of preparatory documents is also highlighted as it is a part of the planning process that is often not formalised. A baseline analysis gathers the existing information about the area, and the process for stakeholder engagement is then designed and agreed upon by the local administration.

The topics marked in pale red in Figure 2 address the issues of cooperating with external stakeholders that have different positions and interests in the development area. This emphasises the need to analyse 


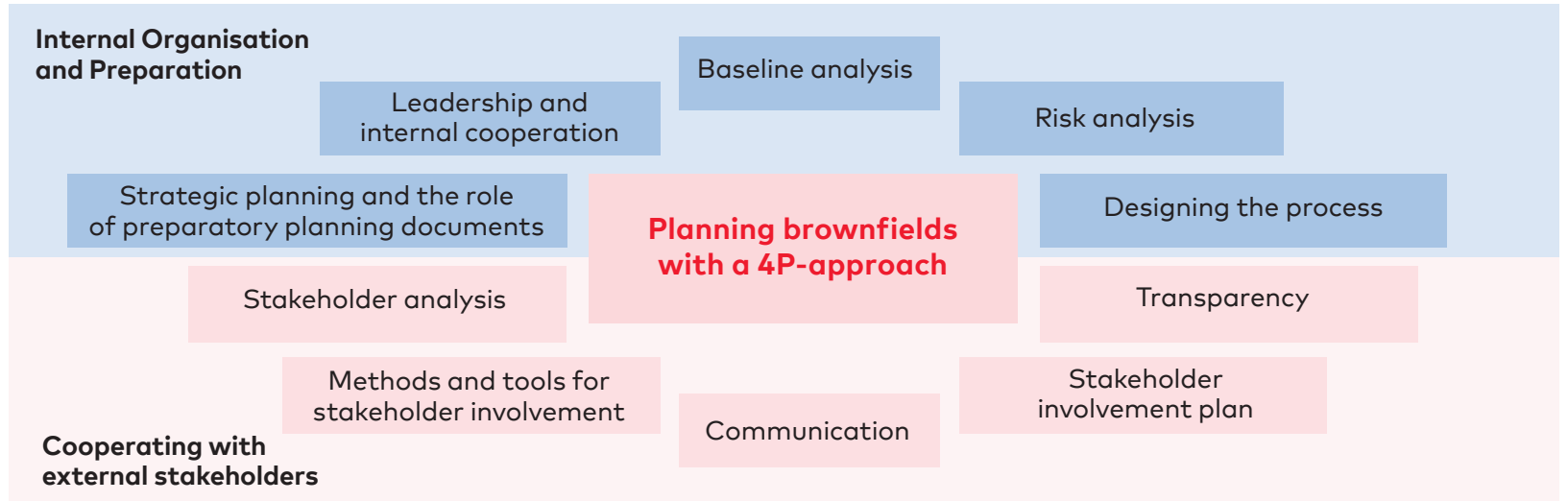

Figure 2: Ten components of the 4P planning process e-Guide, as included in the guide Towards Towards integrated and partnership-based planning of brownfield areas. Available at: https://www.balticurbanlab.eu/materials.

the stakeholders at an early stage, and to identify those who have fewer opportunities to participate but should be active regardless. It stresses the importance of communication and outreach in general but, more specifically, that a variety of different tools for communication and stakeholder engagement should be used in correspondence with the stakeholders that need to be reached - in other words, choosing the right approach for each stakeholder group and carrying out the broader outreach process in a comprehensive way.

\section{LOCAL STORIES}

\section{Brownfield development through spearhead projects in Turku}

The city of Turku is developing a "brownfield belt" around the city centre as part of its "Turku 2029" strategy for sustainable urban development. The Turku Science Park, including the Itäharju brownfield triangle, is one of the city's three spearhead projects, and was initiated with political support in 2016.

Engaging in close cooperation with stakeholders to draw up a vision and an unofficial "Masterplan" for development has been a new experiment for Turku. It has led to the launch of the Turku Future Forum Co-operation Model, which has engaged politicians and other stakeholders in the process and ensured the flow of information between planners and decisionmakers. This process led to the city council approving the vision and the "Turku Science Park Masterplan 2050" as a guideline for further development, and preparing detailed land-use plans for the project area.

\section{Urban Planning App AvaLinn in Tallinn}

To encourage co-creation and to offer an easy way to give feedback on different development plans, the city of Tallinn developed a mobile app. The AvaLinn app - meaning open city - was launched in January 2018 for iOS and Android phones/tablets. AvaLinn makes it possible for local stakeholders to co-create the urban space along with the local council by expressing their ideas and giving feedback on plans.

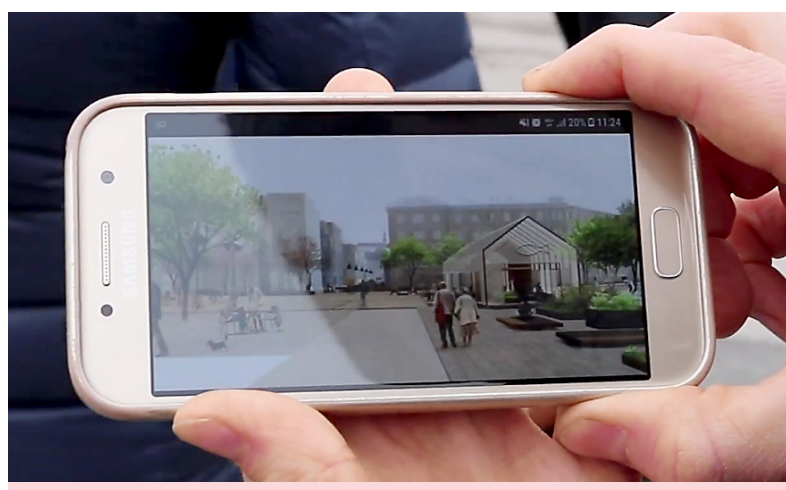

The AvaLinn app. Photo: Kristiina Paju

The app was piloted for the planning of the Skoone Bastion area. Current photos of the area were shown with an interactive map highlighting possible solutions for developing the public space. Users could like or dislike suggestions in the plan, add their own suggestions to the map and comment on other people's suggestions. During the two processes of idea-gathering, more than 3,700 likes and dislikes and 235 ideas/comments were collected from the structural plan of the Skoone Bastion area. The overall opinions and ideas/ comments were analysed by the planning department and used as a basis for dialogue during planning workshops.

\section{FURTHER READING}

- The Baltic Urban Lab Guide: Towards integrated and partnership-based planning of brownfield areas.

- Oliveira e Costa, Sandra, Ilhan, Kellecioglu \& Weber, Ryan (2018) Developing brownfields via public-privatepeople partnerships. Lessons learnt from Baltic Urban Lab. Nordregio report 2018:1. Stockholm: Nordregio.

- Perjo, Liisa (2016) Public-private-people partnerships - a new concept to bring public and private citizens together? Nordregio news \#4.16 People and Cities, 4-6.

- Perjo, Liisa, Fredricsson, Christian \& Oliveira e Costa, Sandra (2016) Public-Private-People Partnerships in Urban Planning. Working paper. Stockholm: Nordregio. 


\section{KEY RECOMMENDATIONS}

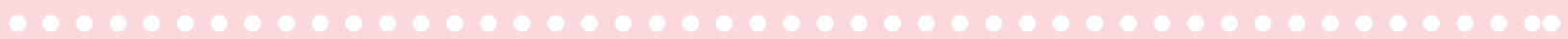

The following list of recommendations is based on the experiences and results of the Baltic Urban Lab project. It offers policy and action points for more efficient and inclusive brownfield development processes, based on support for public-private-people partnerships at local, national and cross-border levels.

The 4P approach emphasises the need to develop brownfield areas in cooperation with the diversity of stakeholders right from the beginning of the planning process, and also emphasises the fact that different stakeholder groups are best engaged using different methods of participation. This can be a key to improve commitment, trust and collective understanding in brownfield regeneration projects.

More equitable planning processes can be enabled by using digital tools for citizen engagement to gather knowledge and support collaboration with target groups that are not typically a part of political discussions. They allow for the ability to synthesise large amounts of input. Visualisation tools, including maps, are valuable communication tools to make the planning process more understandable for non-professionals.

Transparency in the engagement process is what matters most, even though consensus might not always be reached. Local planners need to communicate the planning process in a clear way, including how stakeholder input will be gathered, assessed and used in decision-making processes. Likewise, the results should be communicated in clear, easy-to-understand language.

Brownfield sites are often challenged by the high cost, and high cost uncertainty, of remediating the soil due to contamination from previous uses. The remediation process therefore needs to be better integrated in the planning process from the beginning. Direct communication about the process should be maintained between the various public-sector departments involved, private stakeholders and local citizens.

National level finance for soil remediation is of great importance for local brownfield development. National agencies should also promote and support cooperation between local actors with different responsibilities and promote local cross-sectoral cooperation in urban development. National guidance should be developed in all countries to clarify the potential for brownfield regeneration, including potential funding opportunities.

European funding and support should be provided for cross-border cooperation in the field of urban planning. This encourages cities to exchange and learn from each other as well as to test and experiment new, more open and inclusive planning methods and practices.

\section{ABOUT THE PROJECT}

00000000000000000000000000000000000000000000000

Baltic Urban Lab is an EU-funded project that aims to improve urban planning in the Baltic Sea region. New integrated planning and partnership models for brownfield regeneration have been created and tested in practice in Norrköping, Tallinn, Turku and Riga and made available to all cities in the region to help them in the revitalise of urban space and to support the development of smart, sustainable city districts with high-quality living and working environments.

Local project partners: City of Turku, Norrköping Municipality, Riga City Council City Development Department, Tallinn Urban Planning department.

\section{Research and development partners:}

Nordregio, Union of the Baltic Cities Sustainable Cities Commission (Lead partner), University of Turku.

Associated partners: BOVERKET - the Swedish National Board of Housing, Building and Planning,
Regional Council of Southwest Finland, State Regional Development Agency, VASAB Secretariat, Tallinn University, Turku Science Park Ltd, Turku Technology Properties Group.

More about the project and supplied publications: https://www.balticurbanlab.eu/

Contact information: Johanna Aaltonen, Brahea Centre at the University of Turku, johanna.aaltonen@utu.fi Sandra Oliveira e Costa, Research Fellow, Nordregio sandra.oliveiracosta@nordregio.org Maija Rusanen, Union of the Baltic Cities Sustainable Cities Commission maija.rusanen@turku.fi

Cover photo: Sandra Oliveira e Costa

ISSN 2001-3876

DOI: doi.org/10.30689/PB2018:6.2001-3876 